\title{
ERRATUM
}

M. Berrocal, S. Huerta, J. Rodriguez, M. Perez-Leblic and M.E. Arias (1966)

Short Communication; Effect of water activity on cell growth and phenol oxidase production by Streptomyces cyaneus var. viridochromogenes in surface culture. World Journal of Microbiology \& Biotechnology 12, 1, pp. 101-2.

Below we have reprinted a corrected version of pages 101 and 102 of the above manuscript. We apologise that the original pages were printed incorrectly. The microorganism used in the short communication is a bacteria (actinomycetes) rather than a fungus as mentioned in the text. The text has been corrected accordingly.

\section{Short Communication: Effect of water activity on cell growth and phenol oxidase production by Streptomyces cyaneus var. viridochromogenes in surface culture}

\section{Berrocal, S. Huerta,* J. Rodríguez, M. Pérez-Leblic and M.E. Arias}

In surface cultures of Streptomyces cyaneus var. viridochromogenes, $\mathrm{NaCl}$ depressed water activity $\left(a_{\mathrm{w}}\right)$ without supporting growth. Reducing $a_{w}$ from 0.987 to 0.951 led to 3 - and 4-fold increases in intracellular and extracellular phenol oxidase activities, respectively.

Key words: Phenol oxidase, Streptomyces cyaneus, surface culture.

Lignin-related enzymes such as phenol oxidase and peroxidase could be used to detoxify paper-mill effluents. In order to scale-up the production of phenol oxidase for this and other biotechnological processes, the present study, on the effect of water activity $\left(a_{w}\right)$ on the cell growth and enzyme production of Streptomyces cyaneus var. viridochromogenes in surface culture, was carried out. The strain used produces significant phenol oxidase activity in solid-state fermentations (SSF) (Berrocal et al. 1993). Although water activity $\left(a_{\mathrm{w}}\right)$ is known to be one of the main factors affecting cell growth and enzyme production in SSF, there have been very few reports of its affects on surface cultures (Acuña-Arguelles et al. 1994).

\section{Materials and Methods}

Microorganism and Media

Streptomyces cyaneus var. viridochromogenes was grown on mineral salt medium (Crawford 1978) supplemented with $3 \mathrm{~g}$ yeast extract, $1 \mathrm{ml}$ trace-element solution, $15 \mathrm{~g}$ agar and $40 \mathrm{~g}$ (40-mesh) wheat straw/l. $\mathrm{NaCl}$ (at $8.7,35$ or $70 \mathrm{~g} / \mathrm{l}$ ), glycerol (at 26,101 or $202 \mathrm{~g} / \mathrm{l}$ ) or sucrose (at 92,342 or $649 \mathrm{~g} / \mathrm{l}$ ) was added as a depressor of water activity, to give $a_{w}$ values, measured over $2 \mathrm{~h}$ at $28^{\circ} \mathrm{C}$ with a meter (Aw30001; Ebro), of 0.91 to 0.985 . The inoculum (107 c.f.u./ml) was produced by adding $5 \mathrm{ml} 0.01 \%(\mathrm{w} / \mathrm{v})$ Tween-80 to cultures grown for 6 days at $28^{\circ} \mathrm{C}$ on plates of Bennett medium.

Cell Growth

Cell growth was measured as colony area and as dry wt. Inoculum

M. Berrocal, J. Rodriguez, M. Perez-Leblic and M.E. Arias are with Departamento de Microbiología y Parasitología, Universidad de Alcalá de Henares, 28871 Alcalá de Henares, Madrid, Spain. S. Huerta is with Departamento de Biotecnologia, Universidad Autonoma MetropolitanaIztapalapa, A.P. 55-535, México, D.F., Mexico; fax: 5257244712. "Corresponding author.
$(20 \mu \mathrm{l})$ was added to $25 \mathrm{ml}$ culture medium in a Petri dish and incubated at $28^{\circ} \mathrm{C}$. Colony area was measured on days $I$ and 5 and the difference in the two values was taken as the colony-area increment. To measure dry wt, a disc of Cellophane was placed over the medium in each of several, similar dishes of culture medium before $100 \mu \mathrm{l}$ inoculum were placed on each disc. After 6 days' incubation at $28^{\circ} \mathrm{C}$, the mycelium was removed from each disc, dried on filter paper overnight at $60^{\circ} \mathrm{C}$ and then weighed.

\section{Phenol Oxidase}

Samples of fresh mycelium in $5 \mathrm{ml}$ distilled water with $5 \mu \mathrm{l} 0.01 \%$ $(w / v)$ Tween-80 were stirred for $1 \mathrm{~h}$ at $28^{\circ} \mathrm{C}$. Extracellular enzyme activity was determined by assaying the supernatant produced by centrifuging this suspension for $10 \mathrm{~min}$ at $21,000 \times \mathrm{g}$. Mycelial samples were also washed three times with distilled water, centrifuged $(21,000 \times g, 10 \mathrm{~min})$ and the pellets each resuspended in 2 $\mathrm{ml}$ distilled water and disrupted ultrasonically. After centrifuging the sonicate $(28,000 \times g, 35 \mathrm{~min})$, intracellular activity was determined by assaying the supernatant.

Phenol oxidase activities were determined in the supernatants using $5 \mathrm{mM} \quad 2,2^{\prime}$ azinobis-(3-ethylbenzatiazoline-6-sulphonate)

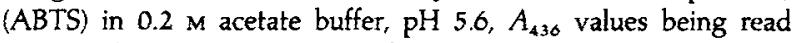
after incubation for $3 \mathrm{~min}$ at $60^{\circ} \mathrm{C}$ (Werner et al. 1970). One unit of activity was defined as that required to liberate $1 \mu \mathrm{mol}$ product per min. Total activities were converted to specific activities (U/ mg protein) after determining protein in the supernatants by the Bradford method, with BSA as standard. Phenol oxidase activity on the agar plates used to determine colony weights, after mycelium and cellophane were removed, was detected qualitatively by pouring a mix of guaiacol, $\alpha$-naftol and $0.1 \mathrm{M}$ ABTS in $96 \%$ ethanol over the agar (Stalper 1978).

\section{Results}

Cell Growth

The maximum increment in colony area was observed when glycerol was used to depress $a_{w}$ to 0.951 . Although 
M. Berrocal et al.



Figure 1. Effect of water activity on colony dry wt $(\square, \square)$ and intracellular $(\mathbf{O}, 0)$ and extracellular $(\Delta, \Delta)$ phenol oxidase activity of Streptomyces cyaneus, after using sucrose (

$\Delta$ ) or $\mathrm{NaCl}(\square, O, \triangle)$ as water-activity depressors.

$\mathrm{NaCl}$ and sucrose gave smaller but similar increments, it was obvious that colony densities with $\mathrm{NaCl}$ were less than those with sucrose. The dry weights of colonies grown with sucrose or $\mathrm{NaCl}$ were therefore determined (Figure 1). Colonies grown with $\mathrm{NaCl}$ decreased in dry wt as $a_{\mathrm{w}}$ decreased. In contrast, the colonies grown with sucrose had higher dry wt at an $a_{w}$ of 0.967 than at one of 0.985 , although dry weights then fell as $a_{w}$ was reduced further.

\section{Phenol Oxidase}

Intra- and extra-cellular, phenol oxidase activities were only determined after using $\mathrm{NaCl}$ or sucrose to depress $a_{\mathrm{w}}$. The two depressors had similar effects on the activities (Figure 1), both intra- and extra-cellular activities increasing as $a_{w}$ decreased from 0.987 to 0.951 (by 3- and 4-fold, respectively). Reducing $a_{w}$ further caused a sharp reduction in both activities. In submerged, shake-flask cultures, in contrast, extracellular, phenol oxidase activity increased 3fold as $\mathrm{NaCl}$ concentration was increased from $0 \%$ to $7 \%$ $(w / v)$ (data not shown). Attempts to demonstrate phenol oxidase activity on agar plates were largely unsuccessful; positive results were only obtained with an $a_{w}$ of 0.951 .

\section{Discussion}

The wide colonies obtained with glycerol and the relatively dense colonies generally obtained with sucrose probably reflect use of these two depressors by the actinomycetes, as carbon sources (see Arias \& Hardisson 1982). The effect of water-activity depressors on the growth of cells of some microorganisms has already been described (Marshal $e t$ al. 1971). In the present study, the $a_{w}$ giving maximum phenol oxidase activities did not correspond to that giving maximum cell growth. Similar results were obtained for the production of cellulase activity by Trichoderma reseii QM9414 and Sporotrichum cellulophilum growing on wheat bran (Kim et al. 1985). However, cell growth of and glucoamylase production by Aspergillus niger seem to be similarly correlated to $a_{\mathrm{w}}$ (Pandey et al. 1994). Troller \& Stinson (1978) noted that decreasing $a_{w}$ also had a varied effect on the production of enzyme activities by bacteria, some activities increasing and some decreasing.

The limited success with demonstrating phenol oxidase activity in the agar plates probably indicates that much of the extra-cellular activity produced by the fungus in surface culture is associated with the cell wall and little diffuses through the cellophane into the agar. The only positive plates were those with optimal $a_{\mathrm{w}}$ for enzyme production.

The experimental methodology used in the present study may prove useful in the study of phenol oxidase from other bacteria and fungi and of other enzymes.

\section{Acknowledgements}

This study was supported by the Spanish Biotechnology Programme (BIO 92-0375). The authors thank the Autonoma Metropolitana University for its collaboration in this research.

\section{References}

Acuña-Arguelles, M., Gutiérrez-Rojas, M., Viniegra-González, G. \& Favela-Torres, E. 1994 Effect of water activity on exo-pectinase production by Aspergillus niger. Biotechnology Letters 16, 23-28.

Arias, M.E. \& Hardisson, C. 1982 Caracterización morfológica y nutricional de 25 cepas de Streptomyces: implicaciones taxonómicas. Boletín de la Real Sociedad Española de Historia Natural Sección Biológica 80, 89-100.

Berrocal, M., López, C.L., Rodríguez, J., Soliveri, J., Copa-Patiño, J.L. \& Pérez-Leblic, M.I. 1993 Optimización de la producción de fenol oxidasa en fermentación en estado sólido, por una cepa de actinomicetos seleccionada. In 14th Congreso Nacional de Microbiologia, Zaragoza, Spain. p. 203. Zaragoza: Octavio y Félez.

Crawford, D.L. 1978 Lignocellulose decomposition by selected Streptomyces strains. Applied and Environmental Microbiology 35, 1041-1045.

Kim, H.K., Hosobuchi, M., Kishimoto, M., Seki, T. \& Ryu, D.D.Y 1985 Cellulase production by a solid state culture system. Biotechnology and Bioengineering 27, 1445-1450.

Marshal, B.J., Ohye, D.F. \& Christian, J.H.B. 1971 Tolerance of bacteria to high concentration of $\mathrm{NaCl}$ and glycerol in the growth medium. Applied Microbiology 21, 363-364.

Pandey, A., Ashakumary, L., Selvakumar, P. \& Vijayalakshrni, K.S. 1994 Influence of water activity on growth and activity of Aspergillus niger for glycoamylase production in solid-state fermentation. World Journal of Microbiology and Biotechnology 10, 485-486.

Stalper, J.A. 1978 Identification of wood-inhabiting Aphyllophorales in pure culture. Studies in Mycology 16, 1-49.

Troller, J.A. \& Stinson, J.V. 1978 Influence of water activity on the production of extra-cellular enzymes by Staphylococcus aureus. Applied and Environmental Microbiology 35, 521-526.

Werner, W., Rey, H.G. \& Wielinger, H. 1970 Uber die Eigenschaften eines neven chromogenes für die Blutzuckerbestimmung nach der GOD/POD-method. Analytical Chemistry 252, 224-228.

(Received in revised form 18 August 1995; accepted 30 August 1995) 